Review

\title{
Linking the Development of Building Sustainability Assessment Tools with the Concept Evolution of Sustainable Buildings
}

\author{
Lihua Liang ${ }^{1}$, Baohua Wen ${ }^{2, *(\mathbb{D})}$, Feng Xu ${ }^{2}$, Jianwei Yan ${ }^{1}$, Xiangqi Yan ${ }^{2}$ and S. Ramesh ${ }^{3,4,5}$ \\ 1 School of Architecture, Tianjin University, Tianjin 300072, China; lianglihua@tju.edu.cn (L.L.); \\ yanjw22@126.com (J.Y.) \\ 2 College of Architecture, Hunan University, Changsha 410082, China; fengxu@hnu.edu.cn (F.X.); \\ yxq-yy@hnu.edu.cn (X.Y.) \\ 3 Center of Advanced Manufacturing and Material Processing, Department of Mechanical Engineering, \\ Faculty of Engineering, University of Malaya, Kuala Lumpur 50603, Malaysia; ramesh79@um.edu.my \\ 4 Department of Mechanical Engineering, Faculty of Engineering, University Teknologi Brunei, \\ Gadong BE1410, Brunei \\ 5 Huanghe Jiaotong University, Zhengzhou 454950, China \\ * Correspondence: wenbaohua@hnu.edu.cn
}

Citation: Liang, L.; Wen, B.; Xu, F.; Yan, J.; Yan, X.; Ramesh, S. Linking the Development of Building Sustainability Assessment Tools with the Concept Evolution of Sustainable Buildings. Sustainability 2021, 13, 12909. https://doi.org/10.3390/ su132212909

Academic Editor: Jorge de Brito

Received: 11 October 2021

Accepted: 14 November 2021

Published: 22 November 2021

Publisher's Note: MDPI stays neutral with regard to jurisdictional claims in published maps and institutional affiliations.

Copyright: (c) 2021 by the authors. Licensee MDPI, Basel, Switzerland. This article is an open access article distributed under the terms and conditions of the Creative Commons Attribution (CC BY) license (https:/ / creativecommons.org/licenses/by/ $4.0 /)$.

\begin{abstract}
With the rapid development of materials science and construction technology, the concept of sustainable building (SB) and the Building Sustainability Assessment Tool (BSAT) have also evolved and developed. Understanding the development of BSAT and SB is of great significance to the sustainable development of the construction industry. This research used the bibliometric method to analyze the development and evolution in the relevant literature on SB and BSAT from 1990 to 2021, and the correlations and differences between them were investigated. We found that there are many common trends in the development of research efforts in SB and BSAT: (1) they focused solely on the environment, in the early days, and only later considered economic and social impacts; (2) the scales with which they are concerned continue to expand, from individual buildings to communities and even cities; (3) key areas, such as energy, materials, resources, indoor environmental quality, high-tech applications, adaptability, and concern for people are being given more attention by both SB and BSAT. On the other hand, the difference between them is that SB research focuses on more macro aspects, such as policy, culture, climate change, while BSAT research is more concerned with micro aspects, such as its system of tools. Furthermore, some current research gaps in the BSAT field are identified, clarifying its future research directions. By linking the evolution of the SB concept and the development of the BSAT research field, this review provides a new and valuable perspective for the sustainable assessment of the construction industry, which, itself, is conducive to the sustainable transformation of this industry, which could contribute greatly to the mitigation of global climate change.
\end{abstract}

Keywords: sustainable building; building sustainability assessment tool; development; evolution; correlation

\section{Introduction}

Global warming, changes in rainfall patterns, extreme weather, etc. have had extensive and profound destructive effects on ecosystems and human survival, and some of these effects are increasing in frequency and intensity [1]. The main reason for the occurrence and strengthening of these situations is human life and production activities [2]. It is clear that, in order to meet the ever-increasing basic needs of the population on the basis of the limited resources of the planet, it is essential to develop a more sustainable development (SD) model for production, consumption and the economy as a whole. 
The construction industry has made important contributions to economic prosperity and social development. At the same time, a large number of construction activities have brought enormous burdens to the environment, contributing to climate change. Research shows that the energy generated by the construction industry accounts for $40 \%$ of the total global energy consumption. It also contributes more than $30 \%$ of greenhouse gas (GHG) emissions [3]. It is predicted that in the next 25 years, the emissions of the construction sector will increase faster than any other sector [4]. The growing population and rapid growth of emerging economies mean that building energy demand will increase by $50 \%$ by 2050 , and global building area is expected to double by then, which will undoubtedly continue to increase building energy consumption and related gas emissions [5]. Therefore, the construction industry is considered to be the most promising sector for rapidly transitioning to SD [6].

Achieving SD is not an easy task, and corresponding assessment tools, technical measures, drivers, action plans, indicators, etc. are essential [7]; for the SD of the construction industry, the use and promotion of building sustainability assessment tools (BSAT) is a vital part of promoting sustainable building development [8-10]. These BSATs originated in Europe and quickly developed into North America, Asia, and then became very popular around the world [11,12]. It is believed that there are more than 600 different BSATs in the world, and this number is increasing [13-16].

In fact, the concept of SD is constantly changing and evolving with the development of technology, materials and people's concerns, and the same is true for the sustainable development of buildings $[17,18]$. As an important tool for assessing the sustainability of buildings, BSAT is continuously upgraded and updated at the same time. And the changes in BSAT can reflect the development of the concept of "sustainable building" (SB) from an important perspective [19]. Therefore, the study on the development of the SB concept and the evolution of BSAT is very important in the realization of SD within the construction industry. This review will focus on the evolution of the concept of SB and the development of BSAT through an analysis of the existing literature and a study of the relevance of the two.

There are many studies on the changes in the concept of SD $[17,20,21]$. However, the number of studies on the evolution of SB and the development of BSAT is relatively small, and systematic research on the correlation between the two is even more rare. However, this kind of research has great theoretical and practical significance, as, by studying the evolution of the concepts and tools of SB, people will be more aware of their changes and latest trends and it is critical to achieving building sustainability goals [22]. At the same time, it can provide more clear and scientific guidance for the future development of these BSATs.

The objectives of this review are:

- $\quad$ Review the formation and development of the SB concept.

- Explore the evolution and development trends of different types of BSAT.

- Correlation analysis between the development of the SB concept and the evolution of BSAT.

- Make recommendations for future BSAT research.

\section{Research Methods}

The research process of this study is divided into three steps (Figure 1):

- Analysis of the related literature on SB and its development.

- Review of the related literature on BSAT and its evolution.

- Comparison and comprehensive analysis of the former two. 


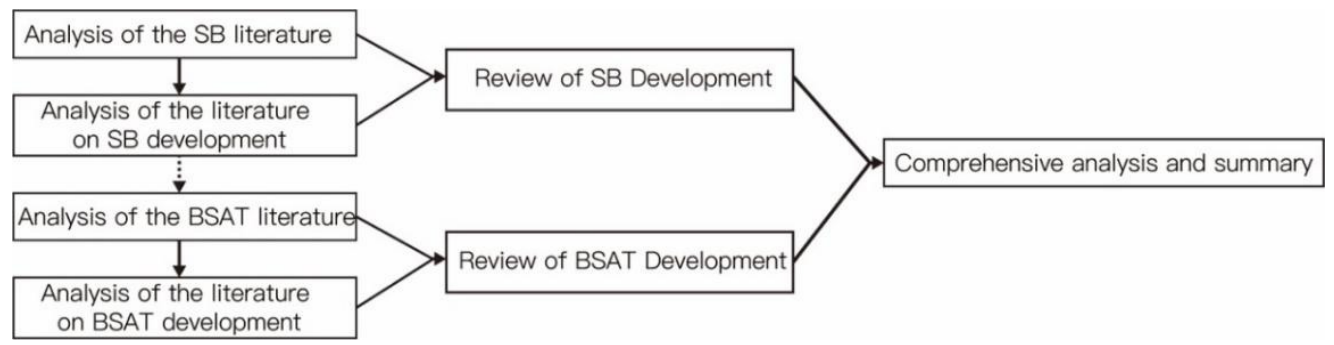

Figure 1. Research process of the study (source: original).

Furthermore, the review of SB- and BSAT-related literature is divided into three levels, by which the research status, research trends, and representative papers are analyzed separately.

- A holistic perspective. The SB- and BSAT-related literatures were scientifically analyzed using bibliometric visualization methods. The aim was to understand the research from earlier circumstances to grasp the current status of this research, and to determine the common patterns and trends therebetween.

- A deeper perspective, in which are screened-out the representative and influential papers directly related to these concepts' development and analyze them in depth.

- Comprehensively analyze the development of SB and the evolution of BSAT and find their relevancies and deviations.

\subsection{Bibliometric Visualization}

Bibliometric visualization has been applied in many fields as a scientific literatureanalysis tool. In recent years, some researchers have used this method to study SB-related fields. From the object of analysis, some studies have analyzed the literature of SD using bibliometric visualization $[23,24]$, while some studies used this method to study sustainable cities and communities [25-28]. However, the number of studies using this method to analyze SB is small [29-32]. From the content of the analysis, most of them are analyzed along criteria such as authors, institutions, countries, number of papers and so on; there are few analyses on the fields and topics themselves.

In addition, their data sources, analysis software and time periods are different, and the analysis content is also different, leading to different analytical results. After analyzing these studies, some problems therein were discovered.

- Their numbers of samples are insufficient.

- Their selected keywords are inappropriate.

- There is no in-depth analysis of the evolution and trends of SB.

- Their time periods do not cover recent years.

In order to avoid the above problems and prevent the duplication of research, this paper will focus on the evolution and trends of SB-related literature from the perspectives of fields, topics, and keywords.

The bibliometric software used in this article is Citespace due to its functions, such as time-slicing and burst-detection [25], which fit the requirements of this study. We chose Web of Science (WOS) as the database because it is the largest accessible citation database, and it has better compatibility with Citespace.

\subsection{Selection of Keywords for Search}

According to the requirements of the three-level analysis, this research divides the relevant keywords into four categories (Table 1). 
Table 1. Keywords used for searching.

\begin{tabular}{|c|c|c|c|}
\hline Class A Keywords & Class B Keywords & Class C Keywords & Class D Keywords \\
\hline $\begin{array}{l}\text { "sustainab * building *" } \\
\text { OR "sustainab * construction *" } \\
\text { OR "sustainab * architecture" } \\
\text { OR "building * sustainability" } \\
\text { OR "architecture sustainability" } \\
\text { OR "construction * sustainability" } \\
\text { OR "green * building *" }\end{array}$ & $\begin{array}{c}\text { (Evaluat* OR Rating } \\
\text { OR Assess *) } \\
\text { AND } \\
(\text { Method *OR } \\
\left.\text { System * OR Tool }{ }^{*}\right)\end{array}$ & $\begin{array}{l}\text { a. Environment * } \\
\text { b. soci }{ }^{*} \\
\text { c. economic * }\end{array}$ & $\begin{array}{l}\text { development OR trend * } \\
\text { OR history OR chang * } \\
\text { OR "evol *" } \\
\text { OR Future OR advance * } \\
\text { OR grow* OR progress * }\end{array}$ \\
\hline
\end{tabular}

Note: * indicates spelling variations in specific search terms.

\subsubsection{The Principle for Determination Keywords}

The determination of these keywords follows the principle (Figure 2); The selected keywords can:

- cover all relevant fields to ensure the comprehensiveness of the search results;

- exclude irrelevant and subjective keywords to ensure the accuracy of search results; and

- ensure the relevance of search results to the research field through the combination of different categories of keywords and the flexible selection of search methods, such as WOS titles and topics.
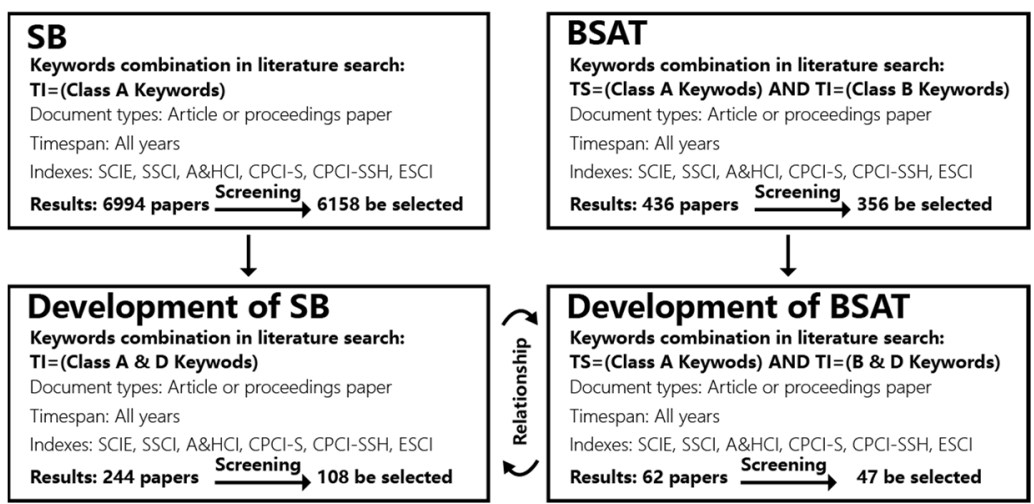

Figure 2. Combination of the keywords in the literature search (source: the authors).

\subsubsection{The Selection Criteria for Papers}

This review mainly covers related academic papers from 1990 through 2021 and has obtained a large number of different research works through search. In order to ensure the accuracy and quantity of the samples, the results of the search were screened objectively. The main selection criteria are as follows:

- The research paper should be relevant to the objectives of this study, that is, related to the BS concept and BSAT development.

- Book chapters and revoked articles are excluded.

- The paper is written in English.

\section{The Development of SB}

SB originated in the late 20th century [33]. Hill et al. [34] studied the concepts of "sustainability" and the "sustainability of buildings" in 1994. However, the focus of this research was on the formation and development of sustainability rather than the sustainability of buildings. Cassidy et al. [35] wrote a research report on the development of SB in 2003. The report details the history of SB, but mainly presents some related milestones and does not study the changes in the concept itself.

Krizankova et al. [36] summarized the development of building sustainability into four decades: 
The first decade, from the early 1970s to the early 1980, was the initial exploration period for building sustainability. Two oil crises in this period prompted people to reexamine the energy and waste of buildings, and people actively experimented with new forms of energy in buildings.

The second decade, from the early 1980s to the early 1990s, was a time when some building sustainability measures moved from the laboratory into practice, and some improved building techniques were used in larger and more complex buildings.

In the third decade, from the early 1990s to the early 2000s, the concept of SB was clarified, during which time many milestones in the history of SB development occurred.

In the fourth decade, from the early 2000s to the early 2010s, the concept of building sustainability was extended to almost all other human-related areas. The European Union released "Architecture and Sustainability" in 2009, and the European Energy Directive was also released in 2010.

Obviously, due to the limitations of the writing era, the study did not take into account the SD of buildings in recent years. In addition, it is not very clear that the 'decade' is properly a phase reflecting the actual situation. This analysis puts the main focus on the factors of time.

Soust-Verdaguer et al. [37] divided the development of the concept of building sustainability into four periods:

- $\quad$ Period 1 (1975-1989): The concept of SB began to emerge, with particular emphasis on the energy efficiency of buildings.

- Period 2 (1990-1999): The building sustainability assessment tool was born and began to have an impact on the SD of the building, with special emphasis on the environmental impact of building materials.

- $\quad$ Period 3 (2000-2009): A large number of BSATs emerged during this period.

- $\quad$ Period 4 (2010-2017): Taking the EU directive on building energy performance as a milestone, the energy performance of buildings began to receive significant attention.

In the WOS, the Class A keywords were searched by topic, and 6994 results were retrieved. Through the screening principles mentioned above 6158 documents closely related to SB were selected. These documents were then analyzed using Citespace.

\subsection{The Literatures Related to $S B$}

The study of SB began in 1990 and has continued for 31 years, to the present day. The study identified a total of 6158 valid documents, indicating that SB is a topic of continuous attention (Figure 2). The number of studies on SB in the first 15 years was not large (within 100 articles per year), and the growth was slow. In the last 16 years, the literature related to SB has increased rapidly, and most of the selected literature was published during this period. Specifically, the change in the number of SB studies can be divided into five phases:

- Phase 1 (1990-1997), the number of studies per year is small; all have single-digit counts.

- Phase 2 (1998-2004), the number of studies per year has increased, but the growth rate is very slow.

- $\quad$ Phase 3 (2005-2009), the number of researches has increased dramatically.

- $\quad$ Phase 4 (2010-2014), the number of researches continues to surge, and the growth rate has accelerated significantly.

- Phase 5 (2015-2021), the number of studies continues to increase, and the rate of increase is further increased.

\subsection{Category Analysis of the Literature}

As shown in Figure 3, the categories of these documents were analyzed using Citespace. Each circle represents a category, blue represents SB involved in this category very early, and red indicates that SB research still exists in this field until today. The blue line represents the early stage of 1990-1999, the green line represents the mid-term of 2000-2010 and the yellow and red lines represent the near-term stage after 2010.The larger the diame- 
ter of the circle, the greater the number of SB-related documents in the category, and the more the color gradation of the "annual ring", the longer the SB lasts in the category.

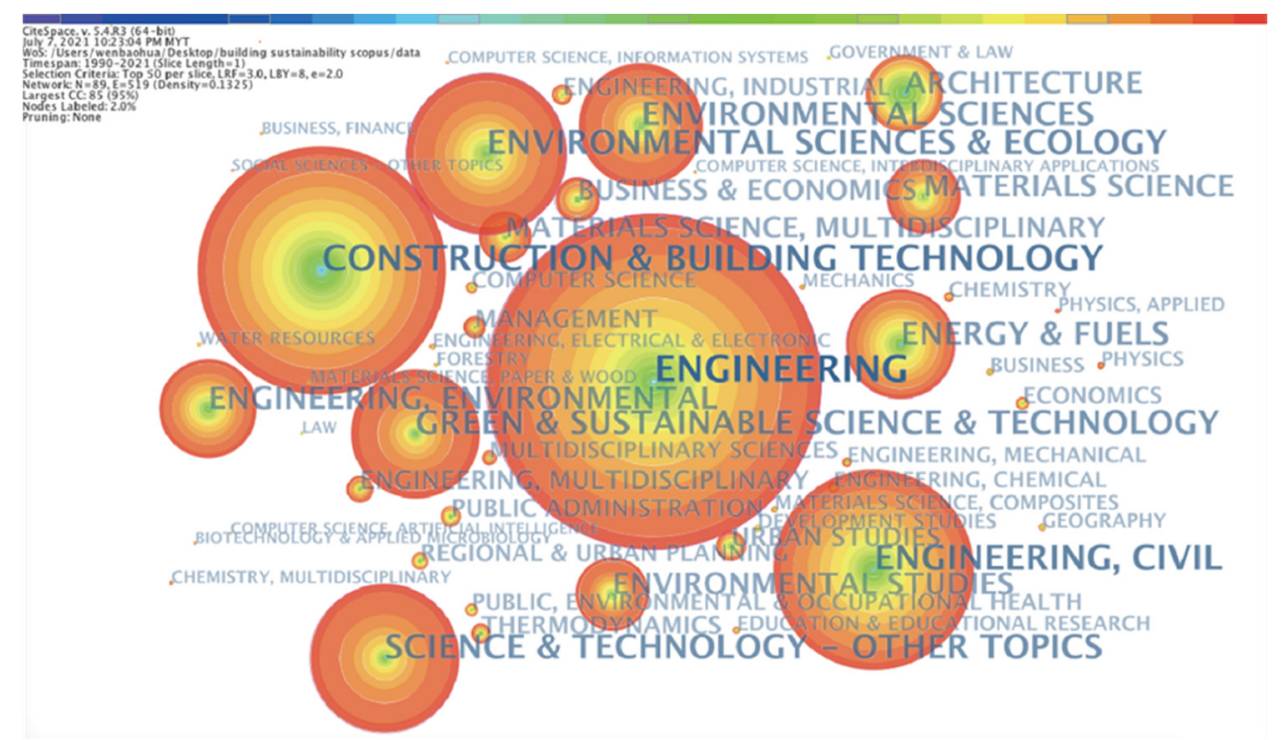

Figure 3. Category analysis of the literature (source: the authors).

These SB-related literatures cover more than 30 categories. The categories with the most literature are "Engineering", "Construction and Building Technology", and "Engineering Civil", and these categories have a long time span. In addition, "Architecture" and "Engineering and Fuels" have a long-time span, and they are all areas that were originally involved in SB research.

The categories "Environmental Science and Ecology", "Green and Sustainable Science and technology", and "Science and Technology—other topics" also contain a large number of documents, and they all appear in the medium term.

It is worth noting that the categories of "Management", "Business and Economics", "Computer Science", "Material Science", "Chemistry", "Physics", "Multidisciplinary Science", etc., although they have a small number of documents, they mainly appear in the near-term. This shows that SB research is developing in these areas.

In short, SB-related research initially focused on the fields of construction, engineering and architecture, and subsequently developed into environmental sciences, sustainable technologies and other fields. In recent years, it has expanded into more fields, such as management science, computer technology, and materials science. The overall trend is that SB has become a multidisciplinary and integrated research topic.

\subsection{Evolution of the $S B$}

First, through analysis and collation, these documents related to SB development are divided into different categories of perspective: the local, technical, external, case, special, global, and tool perspectives (Table 2). The local perspective involves the development, progress, trends, materials, and technology of SB in a specific country or region, having a long-time span and covering the aforementioned Phases $2-5$ of the SB development stages. The technical perspective relates to the potential impact of specific materials and technologies on the development of SB, covering the aforementioned Phases 3-5. The external perspective involves factors such as driving forces, obstacles, and policies that affect the development of SB, covering the aforementioned Phases $4-5$. The case perspective mainly analyzes the development of SB through actual cases, covering the above-mentioned Phase 5. The special perspective mainly discusses specific topics, such as environment, economy, society and culture in the development of SB, covering the above-mentioned Phases $3-5$. The global perspective mainly investigates the development and trend of SB 
from a global scale, covering the above-mentioned Phases $4-5$. The tool perspective mainly refers to the analysis of the development of SB through the research of BSAT, covering the above-mentioned Phases 4-5.

Table 2. Different categories of documents related to SB development.

\begin{tabular}{|c|c|c|c|c|}
\hline Type of Study & Descriptions & Representative Papers & Peak Period & Phase \\
\hline \multirow{3}{*}{$\begin{array}{l}\text { Local } \\
\text { perspective }\end{array}$} & Progress of SB development in a specific region. & [38-42] & 2009-2018 & Phases 3-5 \\
\hline & The status quo and trends of SB in a specific region. & [43-47] & 2013-2018 & Phases $4-5$ \\
\hline & $\begin{array}{c}\text { Development in materials or technologies about SB in } \\
\text { a specific region. }\end{array}$ & {$[17,48-50]$} & 2001-2013 & Phases 2-4 \\
\hline \multirow[t]{2}{*}{$\begin{array}{l}\text { Technical } \\
\text { perspective }\end{array}$} & $\begin{array}{l}\text { The promotion of certain materials to } \\
\text { SB development. }\end{array}$ & [51-56] & 2005-2017 & Phases $3-5$ \\
\hline & The promotion of certain technologies to SB. & [57-60] & 2017-2019 & Phase 5 \\
\hline \multirow{3}{*}{$\begin{array}{l}\text { External } \\
\text { perspective }\end{array}$} & The driving force behind SB development. & [61-65] & 2016-2019 & Phase 5 \\
\hline & Barriers to SB development. & [66-69] & 2017-2018 & Phase 5 \\
\hline & $\begin{array}{l}\text { Research on policies or laws related to } \\
\text { SB development. }\end{array}$ & [70-73] & 2014-2018 & Phases $4-5$ \\
\hline $\begin{array}{c}\text { Case } \\
\text { perspective }\end{array}$ & $\begin{array}{l}\text { Study the development of SB by analyzing } \\
\text { actual cases. }\end{array}$ & {$[74,75]$} & 2018 & Phase 5 \\
\hline \multirow{4}{*}{$\begin{array}{l}\text { Special } \\
\text { perspective }\end{array}$} & The development of SB in environmental impact. & [76] & 2018 & Phase 5 \\
\hline & The development of SB in social impact. & {$[77,78]$} & 2014-2018 & Phases $4-5$ \\
\hline & The development of SB in economic impact. & [79-81] & 2008-2019 & Phases 3-5 \\
\hline & The development of SB in culture and education. & {$[21,82]$} & 2016 & Phase 5 \\
\hline \multirow{3}{*}{$\begin{array}{c}\text { Global } \\
\text { perspective }\end{array}$} & The progress or evolution of SB. & [83] & 2017 & Phase 5 \\
\hline & Research on the development of SB literature. & {$[84,85]$} & 2017-2019 & Phase 5 \\
\hline & The trends of SB. & {$[86,87]$} & 2011-2012 & Phase 4 \\
\hline \multirow{4}{*}{$\begin{array}{c}\text { Tool } \\
\text { perspective }\end{array}$} & Development of BSAT & {$[74,88-90]$} & $2015-2019$ & Phase 5 \\
\hline & Research on the development of BSAT literature. & [32] & 2019 & Phase 5 \\
\hline & Development Research on BSAT in a Specific Country. & [91-95] & 2017-2019 & Phase 5 \\
\hline & Trends of BSATs. & {$[96,97]$} & $2011-2013$ & Phase 4 \\
\hline
\end{tabular}

A large amount of research concerns the development of SB in a specific country [38-40], and the development of BSAT in a particular country [91,98]. In addition, there are many studies on materials, technology, and SB development [99-101]. In recent years, there have been many documents on factors affecting SB development, such as driving forces, obstacles, policies, and laws [61-64]. Some studies are about the "three pillars" of the environment, society and economy, but the number is small [76,77], though research on the evolution of SB and BSAT is a hot topic in recent years $[64,74,83,102]$. The main reason for this is that both SB and BSAT have experienced 31 years of development; thus, now is a good time to summarize them. However, there is not much comprehensive and in-depth research in this field. By analyzing the citation bursts of the topics and keywords of these SB-related literatures (Figure 4), combined with some SB development-related studies, the SB research hotspots and trends were discovered as follows.

\subsubsection{The Evolution of the "Three Pillars"}

It is clear that $\mathrm{SB}$ was originally thought to be a building method that minimizes environmental impact. In the early stages, keywords such as "environmental" and "environmental assessment" appear frequently [103-106]. Then the frequency of economic- and social-related keywords, such as "cost", "economic analysis" and "social impact", began to increase. Therefore, SB has shifted from its initial focus on the environment to focusing on the "three pillars" [32,107,108]. 


\section{Top 60 Keywords with the Strongest Citation Bursts}

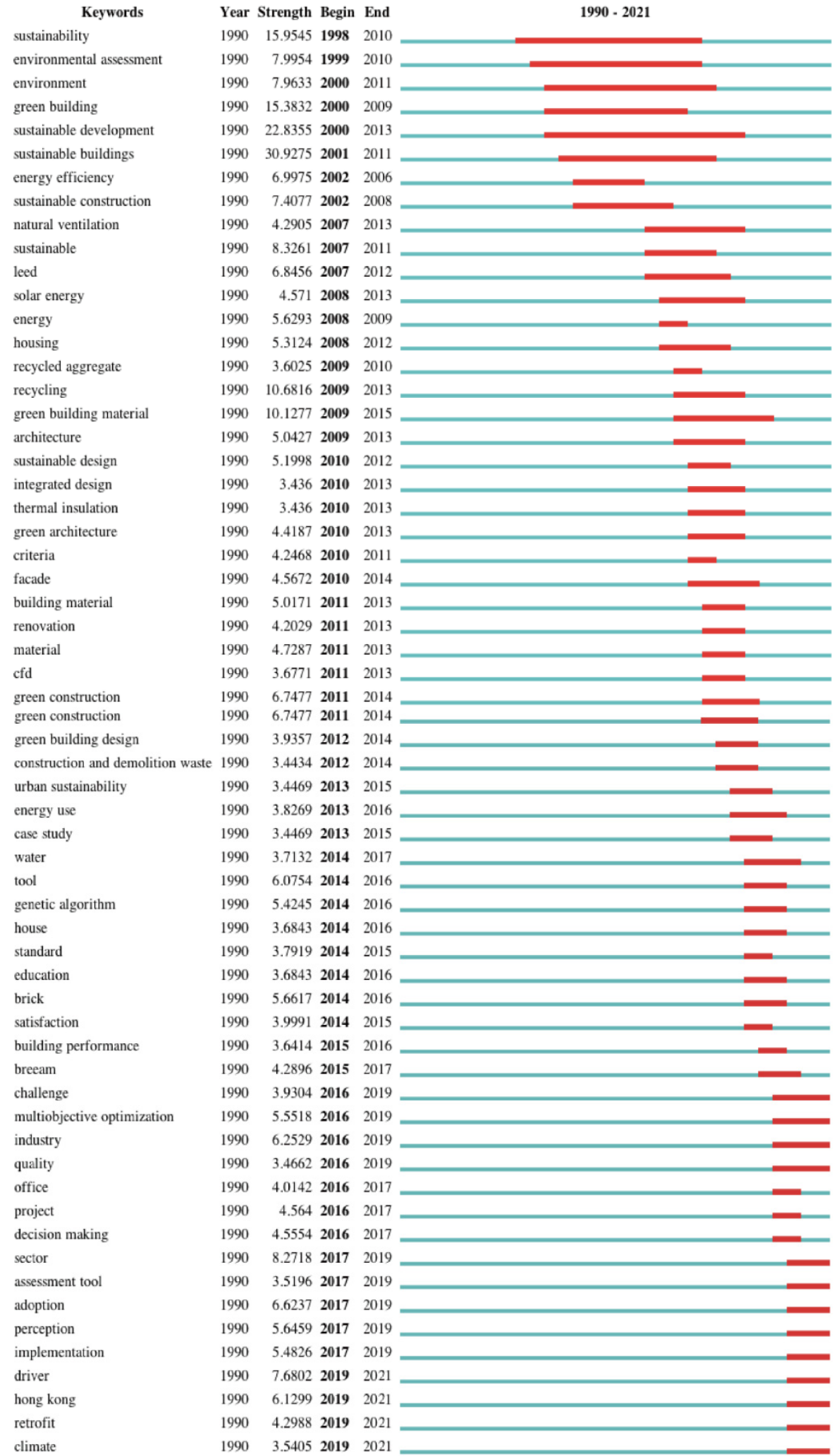

Figure 4. The strongest citation bursts of keywords (source: the authors).

However, some researchers have suggested that the development of the three pillars of SB is not balanced, in that the environment has received greater attention, while the social and economic aspects have not received the attention they deserve $[31,84,109,110]$. 
Zuo et al. [111] pointed out that the social dimension is the weakest link of SB, which is largely ignored. In addition, Doan et al. [112] claimed that the institution and leadership are the fourth pillar of SB, and they believe that SB will have more pillars in the near future.

\subsubsection{Concern for Climate Change}

In the middle of the development of SB, when attention to climate change increased sharply, "carbon emissions", "carbon footprint" and other keywords related to greenhouse gas emissions frequently appeared. This phenomenon continues to this day $[31,109,113]$. Many studies recognize the enormous contribution of architecture to climate change $[3,114]$. Greenhouse gas emissions throughout the life of the building are considered to be one of the most critical SB assessment indicators $[6,115,116]$.

\subsubsection{Resources and Materials}

Resource utilization efficiency was regarded as one of the core indicators of SB in the early stage $[106,117,118]$, and resources and materials have always been the hot spot for studying SB $[110,114,119,120]$. It is worth noting that researchers then began to have a greater interest in "waste", "recycle material", "water", etc., and then the frequency of keywords related to construction materials, such as "concrete" and "hemp", increased. This shows that research has expanded from focusing on material use and material recycling to material properties and new materials. However, there are also different opinions. Darko et al. [31] proposed that the contents of "sustainable concrete" and "renewable resources" in SB research have not received sufficient attention.

\subsubsection{Indoor Environmental Quality (IEQ)}

"Daylight" was paid attention to at an early stage. After that, "air quality", "visual", "thermal comfort", and "indoor environmental quality" have appeared more and more frequently, especially in recent years [31,109,121]. However, Abdellatif and Al-Shamma'a [122] pointed out that there is still a knowledge gap in the field of improving the indoor environment and establishing user perception, and further research in this field is needed.

\subsubsection{Concern for People}

SB's attention to people has generally experienced changes from "health" to "comfort" and "satisfaction" [31,123]. On the one hand, research pays more and more attention to the influence of SB on people. On the other hand, it also reflects a trending change from physical impacts to psychological impacts on people. Wuni et al. [29] pointed out that "attitude assessment" and "post-assessment" have become one of the top ten SB research hotspots. Zuo and Zhao [109] pointed out that SB's research has shifted from focusing only on construction itself to the interaction between buildings and users. Marjaba and Chidiac [124] pointed out that people's health and environmental awareness is the most important driving force for SB development. On the other hand, Yuan and Zuo [125] suggest that SB should pay attention to health, safety, comfort, and accessibility. Berardi [110] also pointed out that SB should pay more attention to people's well-being, user satisfaction and other aspects.

\subsubsection{Technical Aspects}

Although most studies have found that advanced technologies related to SB are a wide range of research areas [29,30,109]. However, some people disagree, and Darko et al. [31] pointed out that there are obvious shortcomings in topics such as "sustainable concrete" and "integrated advanced technology" in SB research. According to the findings of this study, SB focused on energy technologies, such as "photovoltaic technology", in the early stage, and then turned to green construction technologies, such as "prefabricated technology", "enclosure structure", and "green roof". It should be said that "advanced technology" has always been a research focus and a research trend. 


\subsubsection{Different Scales}

SB has experienced a leap from "sustainable building" to "urban", "community", "urban" and then "infrastructure". SB no longer likes to focus on the building itself, and is beginning to grow toward a larger and more complex level [126]. The expansion to a larger scale has had a positive impact on the development of SB, because buildings are often inseparable from the surrounding environment and facilities. Larger assessments in communities or cities will involve broader and more complex factors, fro which the accuracy of results will be greatly increased [110]. Yet, Pan and Ning [113] pointed out that research on SB at the community or city levels is not enough. However, the study clearly did not take into account the latest research trends. Ghoddousi et al. [127] also pointed out that research on the use of sustainability in infrastructure is not enough.

\subsubsection{Adaptability and Resilience}

SB's adaptability includes many aspects, including adaptability to climate change, adaptability to different geographical backgrounds, adaptability to dynamic needs, etc. [109,126,128]. Improving the building's adaptability and resilience has become a topic of increasing concern because it ensures the building's ability to maintain and metabolize for a long time [110,129].

\subsubsection{Culture and Aesthetics}

At present, SB pays little attention to related aspects such as "aesthetics" and "culture", while some studies point out that it is important to combine humanities, aesthetics, culture, and SB [126,130,131]. Berardi [110] emphasized improving aesthetics and preserving cultural values as important attributes of SB. The survey by Su and Lin [132] also found that it is important to include humanities and aesthetics in the SB. Chehrzad et al. [131] pointed out that the challenge of integrating aesthetics and cultural aspects into SB is that the indicators that can characterize them are mostly qualitative and highly dependent on expert judgment, resulting in uncertainty about the objectivity and accuracy of such evaluations.

\subsubsection{Innovation}

Under the influence of the expected climate change and resource shortage in the future, the imperatives of social change and technological innovation have furnished SB with huge opportunity for innovation and development [133]. Some studies also show that $\mathrm{SB}$ is paying more and more attention to innovation [109,131]. Shan and Hwang [14] believe that the introduction of innovation points can encourage, recognize and reward those measures that can prompt SB to find new breakthrough points and development fulcrums in technology, design, and process.

\subsubsection{Project Management}

Although many studies have shown that the delivery and management of SB projects has gradually become a research area of SB hotspots [22,29], but Darko et al. [31] pointed out the lack of "project management"-related content in SB research. In fact, SB does have shortcomings in project management during the implementation process [134,135]. Due to this, there is much research on this topic. Wu and Low [118] suggested that project management should be considered both in terms of process and practice while meeting green requirements.

\subsubsection{Factors Affecting Development}

Green building codes, policies and regulations are important guarantees and a basis for the development of SB, so such topics have received much attention $[29,136,137]$.

"Barriers", "Drivers", "Success Factors", "Risks", etc. are frequently used keywords in recent years. These aspects are also some of the topics of most concern in the development of SB [62-64,66-68]. However, Ahmad et al. [22] pointed out that the current research on these topics is fragmented, which may hinder the further development of SB. Zuo and Zhao [109] suggested that research should be strengthened in areas such as SB policies and incentives. 
In addition, since "communication" and "cooperation" are also crucial to the development of SB, many studies suggest that international cooperation should be strengthened to promote SB development [31,138,139]. Pan and Ning [113] argued that SB research does not combine end-user perspectives with the perspectives of relevant professionals, and there are significant information and communication gaps between multiple stakeholders.

\section{Development of BSAT}

\subsection{The Evolution of BSAT}

BSATs aim to measure and assess compliance with sustainability principles, reduce the environmental burden of the buildings they prescribe, and mark them accordingly. Sustainability rating tools are especially important in distinguishing the level of building sustainability [140,141].

Wen et al. [102] divided the evolution of global BSATs into three stages, based on their sustainability concerns.

- $\quad$ Phase 1 (1990-1997), the initial development period; the number of BSATs is relatively small.

- $\quad$ Phase 2 (1998-2008), the rapid development period; a large number of new BSATs were developed.

- $\quad$ Phase 3 (after 2009), the stable development period; the number of BASTs has basically stabilized.

Moreover, the keywords in 356-item BSAT-related literature review were statistically and categorized. It was found that most of the literature is about BSAT assessments, where "energy" and "environmental impact" are the most frequently occurring keywords. Second, there are many keywords related to technology, development, and tools. Furthermore, some common topics and related opinions in the development of BSAT are identified as follows.

\subsubsection{The Evolution of the "Three Pillars"}

Similar to SB development, BSAT is also undergoing a process from environmental to social and economic expansion $[107,138,142]$. Khan et al. [114] have recommended combining BSAT with life-cycle costing to determine the various economic costs associated with SB. Martek et al. [107] found that some social equity-related content, such as affordable housing, convenient public facilities, quality of the work environment, etc., are entering BSAT. Zuo and Zhao [109] believe that the integration of economic, social and other aspects in the BSAT indicates that people are more and more accepting the "triple bottom line". However, Illankoon et al. [143] found that almost all BSAT's focus on social sustainability focused on health and well-being, while other social aspects were rarely considered, and they pointed out that BSAT largely ignored economic sustainability. A recent survey by Wen et al. [102] shows that the consideration of environmental indicators in the development of BSAT continues to decline, while social indicators and economic indicators have a slight upward trend.

\subsubsection{Energy and Resources}

The efficient use of energy performance and resources has always been the focus of BSAT $[6,14,131,144]$. In fact, BSAT development was originally based on a single, energyrelated parameter. However, this assessment, along a single dimension, has received much criticism because it cannot assess complex sustainability [139]. In addition, there are many studies that have cast doubt on the energy performance and resource usage of BSAT-certified buildings [12,145].

\subsubsection{LCA}

As an important tool and method, LCA has always been a hot topic in BSAT research. Due to LCA's comprehensive and systematic environmental assessment methodology, LCA tools are integrated, to varying degrees, in many green building-rating systems [146,147]. Many studies have pointed out that there is great potential to combine LCA with BSAT $[17,114,148]$. The main advantage of integrating LCA with BSAT is in helping to create a robust quantitative 
assessment method [138]. Some studies explore ways to integrate LCA into BSAT [149]. However, Ismaeel [150] pointed out that LCA is only partially integrated by BSAT and is not reflected at the overall-system level.

\subsubsection{System Aspect}

The BSAT system has been extensively studied. "Assessment indices", "criteria", "indicators", etc. are the most common keywords for studying BSAT systems. The indicator system is the core aspect of the BSAT and is critical to the legitimacy of the BSAT [151]. The development of the building sustainability indicator system has two forms; one is top-down and developed by the government based on expert opinions [152]. The other is bottom-up - it is dominated by the public [153] — but this important system has been fiercely questioned because of its subjectivity and irrationality [154-156].

\subsubsection{Compare Research}

As shown in Table 3, a large number of comparative studies have been carried out on the BSAT indicator system at different levels, including categories, subcategories, criteria, and indicators [10]. Among them, the number of studies on the criteria level is the largest, and they focus on the weight comparison of different levels of indicator systems. Li et al. [157] divided these comparative studies into general, categorical, criterion, and indicator comparisons according to the research objects. On this basis, Wen et al. [102] collectively referred to these studies as horizontal comparative studies and pointed out the lack of adequate longitudinal research in the BSAT field. Moreover, according to Liang et al. [16], there are five problems in the literature related to the comparative study of BSAT:

- providing equal conditions of comparison;

- $\quad$ giving specific calculation methods;

- $\quad$ establishing a unified index classification framework;

- clarifying the classification process of indicators; and

- considering the multidimensional properties of indicators.

Table 3. Analysis of BSAT comparative literature.

\begin{tabular}{|c|c|c|c|c|c|c|}
\hline \multirow{2}{*}{ NO } & \multicolumn{5}{|c|}{ Indicator System } & \multirow{2}{*}{ Reference } \\
\hline & Scope & Category & Criteria & Indicator & Weight & \\
\hline 1 & & & 0 & & 0 & [158] \\
\hline 2 & & 0 & 0 & & 0 & [138] \\
\hline 3 & 0 & & 0 & & 0 & [143] \\
\hline 4 & 0 & 0 & 0 & & 0 & [159] \\
\hline 5 & 0 & 0 & 0 & & 0 & [160] \\
\hline 6 & & 0 & 0 & & 0 & [161] \\
\hline 7 & 0 & & & & 0 & [89] \\
\hline 8 & & 0 & 0 & & 0 & [162] \\
\hline 9 & & 0 & 0 & & 0 & [14] \\
\hline 10 & & 0 & 0 & & 0 & [144] \\
\hline 11 & & & 0 & & & [163] \\
\hline 12 & & & 0 & 0 & 0 & [164] \\
\hline 13 & & 0 & 0 & & 0 & [165] \\
\hline 14 & & & 0 & & 0 & [166] \\
\hline 15 & 0 & 0 & 0 & & 0 & [167] \\
\hline 16 & & & 0 & & 0 & [168] \\
\hline 17 & & 0 & 0 & & 0 & [169] \\
\hline 18 & 0 & & 0 & & 0 & [170] \\
\hline 19 & & & 0 & 0 & & [171] \\
\hline
\end{tabular}




\subsubsection{Technology Integration and Innovation}

Advanced information and communication technologies will play a key role in helping to develop green buildings, while "Building Information Modeling", "Artificial Intelligence", "big data", etc. appear more frequently. This shows that the development of BSAT is being combined with the latest technology $[109,128,172]$. On the other hand, Darko et al. [31] believe that future research should be more extensively conducted on the collection of advanced technologies, such as BSAT and AI and big data. Lu et al. [58] pointed out that there are still many weak links that need to be overcome when combining BIM with BSAT. In addition, BSAT's innovation has received increasing attention in recent years $[14,131]$.

\subsubsection{Concern for People}

The frequency of keywords such as "thermal comfort", "visual comfort", "health", and "indoor environmental quality" is strengthening [173-175]. Like SB's development trend, BSAT is also strengthening its focus on human comfort and health [14,109,128,131,176]. However, some studies have expressed different views. Gou et al. [177] pointed out that BSAT has great challenges in IEQ because it defines the physical environment relatively narrowly, affecting the perception and satisfaction of occupants. Xue et al. [178] also pointed out that BSAT ignores the type of building and the associated needs of different occupants. Yeang [179] pointed out that BSAT has not fully met the user's "health" standard. "Green" buildings are no more productive than those that are reasonably designed, because indoor environmental quality and methods of measuring actual productivity are inaccurate [180].

On the other hand, Zuo and Zhao [109] also pointed out that BSAT needs to pay more attention to special populations such as the elderly, students, and teachers.

\subsubsection{Expanded Scale}

Although BSAT focuses on the sustainability of buildings, such as schools, hospitals, residential buildings, commercial buildings, data centers, etc. [31], it also strides toward other larger scales, such as the "city," "community," "urban," "infrastructure," and so on [166,181-183]. However, Wu et al. [184] pointed out that little research has been conducted on how to effectively transition green buildings to green communities. By analyzing LEED ND, they found that their economic, social and environmental credit allocations were uneven.

\subsubsection{Different Phases}

At the beginning of BSAT development, more attention was paid to the design phase, although some studies indicate that BSAT may play the biggest role in the design phase $[33,185]$. Yet it has also been criticized for the lack of an overall life-cycle perspective $[138,186,187]$. It is a fact, however, that BSAT is developing into the entire life-cycle and gradually achieving coverage for design, construction, operation, and demolition [12]. Still, some studies indicate that most green buildings are only certified at the design stage, while green certification at the operational stage is rare $[163,188]$.

\subsubsection{Adaptability}

BSAT's flexibility is critical to its adaptability [110]. Numerous studies have confirmed that most BSATs are designed according to local climate and geographical conditions $[105,158,189,190]$. BSATs' adaptability to climate change and different geographical characteristics needs to be strengthened [191-194]; this will be an important direction for its development $[128,144]$. Some studies suggest that BSAT should assign weights for various credits based on local and regional conditions. This process should reflect the cultural characteristics of different countries and regions $[12,139,166]$. In addition, some commercial BSATs have also gained attention to the market [97]. 


\subsubsection{Ease of Use}

Some studies have found that some users think that BSAT is too complicated and takes too long to use $[12,139,195]$, restricting their promotion and development. Kaatz et al. [192] accused BSAT of technical language barriers to users. Therefore, the importance of the simplicity and ease of use of the BSAT system is emerging [114]. This requires BSAT to be user-friendly and easy to operate $[110,196]$.

\section{Research Findings}

This review analyzed previous literature related to SB and BSAT and discussed the development of the SB concept and the evolution of BSAT. After that, the contributions and limitations of the relevant researchers were evaluated. The final goal is to find out the relevance of the development direction of SB and BAST and to find the knowledge gap in this research area. We hope to provide reference for future-related research.

This review used the bibliometric method to analyze 6158 SB-related works and 356 BSAT-related works. Subsequently, based on the appropriate combination of keywords in the literature search, 108 and 47 documents related to the evolution of SB and BSAT were further identified and analyzed in depth. The evolution of and correlations between the two emerged (Figure 5). The specific findings follow.

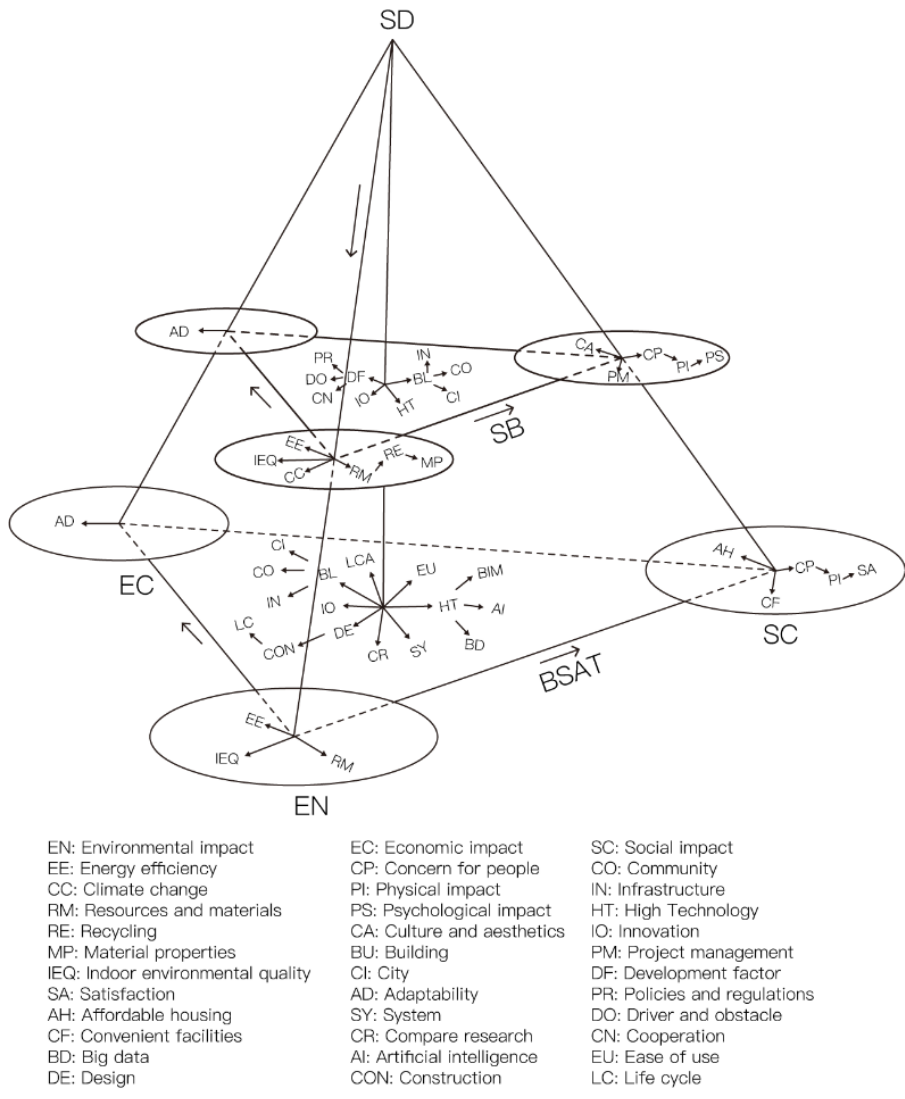

Figure 5. Correlation between SB and BSAT development (source: original).

\subsection{Commonalities between the Development of $S B$ and BSAT}

- Both SB and BSAT initially focused on environmental impacts and then began to focus on social and economic aspects. However, the current social and economic concerns are not enough, and this will be a long-standing topic of debate in the future.

- Energy performance and resource efficiency have received the greatest attention from $\mathrm{SB}$ and $\mathrm{BSAT}$, and have an important position in the entire development process of SB and BSAT. 
- $\quad \mathrm{SB}$ and BSAT initially focused on the sustainability of building units, and both of them turned their attention, later, to a larger scope, e.g., beginning to pay attention to the sustainability of communities and cities.

- The interest of SB and BSAT in IEQ is increasingly growing, and this trend has become more apparent in recent years.

- $\quad$ Both SB and BSAT are more and more concerned about people. From the beginning, SB and BSAT mainly focused on physical aspects, such as sunlight and health, and now is increasingly focusing on psychological aspects, such as user experience and satisfaction.

- Adaptability is receiving more and more attention. The SB focuses on adaptability to climate change, different geographies, and changing needs, while the BSAT focuses on improving resilience to different geographies through a flexible indicator system.

- The use of high technology and the encouragement of innovation are common trends in the development of SB and BSAT. SB's integration of high technology lies mainly in green construction technologies, while BSAT's focus on high technology is in information technologies, such as artificial intelligence and big data.

\subsection{Personality Trends in SB Development}

Project management, culture, aesthetics, climate change, etc. are all trends in the development of SB. In addition, SB is also concerned with factors that affect its development, such as drivers, obstacles, policies, regulations, and so on. These topics are relatively rare in the study of BSATs.

\subsection{Personality Trends in BSAT Development}

- BSATs initially focused only on the design phase, and later began to consider other stages of construction, renovation, renovation, etc., to cover the entire life cycles of buildings.

- A comparative study of different BSATs is a hot topic, where indicator systems and weights are the focus of comparison.

- Critical analysis of the BSAT system is a research trend because of the subjective nature of its indicator system.

- The ease-of-use of a BSAT has also received a lot of attention because it directly affects its promotion and development.

\subsection{Relevance and Difference between SB and BSAT Development}

There are many common trends and research areas in the development of SB and BSAT, but there are also some differences. Aspects of SB's focus are more on macro aspects, such as policy, culture, and climate change. The study of the BSAT focuses more on micro aspects, such as the system of tools, ease of use, and so on. The development of SB provides a broader topic, while BSAT research operates more at the application and operational levels.

\section{Conclusions}

There has been much research on SB and BSAT before this work (6158 and 356 related documents were identified, respectively), and the analysis angles thereof are different, but they have played a positive role and contributed to the development of SB and BSAT. Yet, by analyzing these documents, some research gaps were discovered. Although the study of SB and BSAT development has great significance, the research on both of the topics is obviously insufficient (only 108 and 47 related documents were identified, respectively). The number of such studies has increased in recent years, but most studies are not deep enough in their analyses. Many studies focus on one of SB or BSAT, and there are few studies on the correlation and differences between SD, SB, and BSAT development.

There are deficiencies in the research methods for studying the BSAT. Most studies have not developed a unified assessment framework for different BSATs, resulting in insufficient accuracy of results. Many studies have focused on the balance between the 


\begin{abstract}
"three pillars" of SB and BSAT, but there is little research on the balance between generations and fairness.

Understanding the development of BSAT and SB is important for the sustainable development of the construction industry and for global climate change. This paper reviewed the relevant literature for SB and BSAT from 1990 through 2021, discussed the development of the two, and analyzed the correlations and differences between them. Since this review was based on an analysis of previous literature, its results are directly related to the selected sample, which may also result in some gaps, with respect to the actual situation. It is suggested that, in the future, more direct research on the evolution of BSATs themselves, in different historical periods, should be carried out.
\end{abstract}

Author Contributions: Author Contributions: Conceptualization, L.L. and B.W.; methodology, L.L. and B.W.; formal analysis, L.L. and B.W.; investigation, L.L. and B.W.; resources, F.X. and J.Y.; writing-original draft preparation, L.L. and B.W.; writing-review and editing, S.R.; visualization, X.Y.; supervision, F.X. and J.Y.; project administration, F.X. and J.Y. All authors have read and agreed to the published version of the manuscript.

Funding: This research was funded by Hunan Provincial Department of Natural Resources (fund number 2021B08) and Hebei Province Philosophical and Social Science Fund Project (fund number HB20YJ002).

Institutional Review Board Statement: Not applicable.

Informed Consent Statement: Not applicable.

Data Availability Statement: No new data were created or analyzed in this study. Data sharing is not applicable to this article.

Conflicts of Interest: The authors declare no conflict of interest.

\title{
References
}

1. Unep World Resources Report 2010-2011. Available online: https:/ /www.wri.org/publication/world-resources-report-2010-2011 (accessed on 16 November 2021).

2. McMullen, C.P.; Jabbour, J.R. Climate Change Science Compendium 2009; United Nations Environment Programme: Nairobi, Kenya, 2009.

3. Dtie, U. Buildings and Climate Change. Available online: https://www.uncclearn.org/wp-content/uploads/library/unep207 .pdf (accessed on 13 November 2021).

4. U.S. Energy Information Administration (EIA). Annual Energy Outlook 2013; U.S. Energy Information Administration (EIA): Washington, DC, USA, 2013; pp. 60-62.

5. Renewables Global Status Report. Available online: https://www.ren21.net/wp-content/uploads/2019/05/REN21_GSR2016_ FullReport_en_11.pdf (accessed on 13 November 2021).

6. GhaffarianHoseini, A.; Dahlan, N.D.; Berardi, U.; GhaffarianHoseini, A.; Makaremi, N.; GhaffarianHoseini, M. Sustainable energy performances of green buildings: A review of current theories, implementations and challenges. Renew. Sustain. Energy Rev. 2013, 25, 1-17. [CrossRef]

7. Plessis, C.D. Sustainable development demands dialogue between developed and developing worlds. Build. Res. Inf. 1999, 27, 378-389. [CrossRef]

8. Zimmerman, A.; Kibert, C.J. Informing LEED's next generation with the natural step. Build. Res. Inf. 2007, 35, 681-689. [CrossRef]

9. Plessis, C.D.; Cole, R.J. Motivating change: Shifting the paradigm. Build. Res. Inf. 2011, 39, 436-449. [CrossRef]

10. Zhang, X.; Zhan, C.; Wang, X.; Li, G. Asian green building rating tools: A comparative study on scoring methods of quantitative evaluation systems. J. Clean. Prod. 2019, 218, 880-895. [CrossRef]

11. Sev, A. A comparative analysis of building environmental assessment tools and suggestions for regional adaptations. Civ. Eng. Environ. Syst. 2011, 28, 231-245. [CrossRef]

12. Berardi, U. Sustainability Assessment in the Construction Sector: Rating Systems and Rated Buildings. Sustain. Dev. 2012, 20, 411-424. [CrossRef]

13. Saunders, T. A Discussion Document Comparing International Environmental Assessment Methods for Buildings. Available online: https://tools.breeam.com/filelibrary/International\%20Comparison\%20Document/Comparsion_of_International_ Environmental_Assessment_Methods01.pdf (accessed on 13 November 2021).

14. Shan, M.; Hwang, B.G. Green building rating systems: Global reviews of practices and research efforts. Sustain. Cities Soc. 2018, 39, 172-180. [CrossRef] 
15. McCreadie, M. Client Report: BRE Subcontract: Assessment of Sustainability Tools. Available online: https://download.sue-mot. org/envtooleval.pdf (accessed on 13 November 2021).

16. Liang, L.; Wen, B.; Musa, S.N.; Onn, C.C.; Ramesh, S.; Yan, J.; Wang, W. Rectify the performance of Green Building Rating Tool (GBRT) in sustainability: Evidence from ISO 21929-1. J. Clean. Prod. 2021, 278, 123378. [CrossRef]

17. Sinha, A.; Gupta, R.; Kutnar, A. Sustainable Development and Green Buildings. Drv. Ind. 2013, 64, 45-53. [CrossRef]

18. Ruichi, F. Research on the Optimization of Chinese Green Building Evaluation Criteria Based on Perspective of Project Management; Shandong Jianzhu University: Jinan, China, 2017.

19. Zuo, J.; Pullen, S.; Rameezdeen, R.; Bennetts, H.; Wang, Y.; Mao, G.Z.; Zhou, Z.H.; Du, H.B.; Duan, H.B. Green building evaluation from a life-cycle perspective in Australia: A critical review. Renew. Sustain. Energy Rev. 2017, 70, 358-368. [CrossRef]

20. Wen, B.; Musa, S.N.; Onn, C.C.; Ramesh, S.; Liang, L.; Wang, W.; Ma, K. The role and contribution of green buildings on sustainable development goals. Build. Environ. 2020, 185, 107091. [CrossRef]

21. Wu, S.R.; Fan, P.L.; Chen, J.Q. Incorporating Culture into Sustainable Development: A Cultural Sustainability Index Framework for Green Buildings. Sustain. Dev. 2016, 24, 64-76. [CrossRef]

22. Ahmad, T.; Aibinu, A.A.; Stephan, A. Managing green building development-A review of current state of research and future directions. Build. Environ. 2019, 155, 83-104. [CrossRef]

23. Hassan, S.-U.; Haddawy, P.; Zhu, J. A bibliometric study of the world's research activity in sustainable development and its sub-areas using scientific literature. Scientometrics 2014, 99, 549-579. [CrossRef]

24. Quental, N.; Lourenço, J.M. References, authors, journals and scientific disciplines underlying the sustainable development literature: A citation analysis. Scientometrics 2012, 90, 361-381. [CrossRef]

25. Wang, M.-H.; Ho, Y.-S.; Fu, H.-Z. Global performance and development on sustainable city based on natural science and social science research: A bibliometric analysis. Sci. Total Environ. 2019, 666, 1245-1254. [CrossRef]

26. Ferrer, A.L.C.; Thomé, A.M.T.; Scavarda, A.J. Sustainable urban infrastructure: A review. Resour. Conserv. Recycl. 2018, 128, 360-372. [CrossRef]

27. Fu, Y.; Zhang, X. Trajectory of urban sustainability concepts: A 35-year bibliometric analysis. Cities 2017, 60, 113-123. [CrossRef]

28. de Jong, M.; Joss, S.; Schraven, D.; Zhan, C.; Weijnen, M. Sustainable-smart-resilient-low carbon-eco-knowledge cities; making sense of a multitude of concepts promoting sustainable urbanization. J. Clean. Prod. 2015, 109, 25-38. [CrossRef]

29. Wuni, I.Y.; Shen, G.Q.P.; Osei, R.O. Scientometric review of global research trends on green buildings in construction journals from 1992 to 2018. Energy Build. 2019, 190, 69-85. [CrossRef]

30. Darko, A.; Chan, A.P.C. Critical analysis of green building research trend in construction journals. Habitat Int. 2016, 57, 53-63. [CrossRef]

31. Darko, A.; Chan, A.P.C.; Huo, X.; Owusu-Manu, D.-G. A scientometric analysis and visualization of global green building research. Build. Environ. 2019, 149, 501-511. [CrossRef]

32. Díaz-López, C.; Carpio, M.; Martín-Morales, M.; Zamorano, M. Analysis of the scientific evolution of sustainable building assessment methods. Sustain. Cities Soc. 2019, 49, 101610. [CrossRef]

33. Crawley, D.; Aho, I. Building environmental assessment methods: Applications and development trends. Build. Res. Inf. 2010, 27, 300-308. [CrossRef]

34. Hill, R.C.; Bergman, J.G.; Bowen, P.A. A Framework for the Attainment of Sustainable Construction. Available online: https: / / www.irbnet.de/daten/iconda/CIB_DC24776.pdf (accessed on 13 November 2021).

35. Cassidy, R.; Wright, G.; Flynn, L. White paper on sustainability: A report of the green building movement. Building design and construction; Reed Business Information: New York, NY, USA, 2003; pp. 6-10.

36. Krizankova, A.; Keppl, J. Sustainable Architecture in Slovakia after the Year 1990. J. Sustain. Archit. Civ. Eng. 2015, 12, 34-43. [CrossRef]

37. Soust-Verdaguer, B.; Llatas, C.; Garcia-Martinez, A. Critical review of bim-based LCA method to buildings. Energy Build. 2017, 136, 110-120. [CrossRef]

38. Chua, S.C.; Oh, T.H. Green progress and prospect in Malaysia. Renew. Sustain. Energy Rev. 2011, 15, 2850-2861. [CrossRef]

39. Li, J.; Wu, C.; Qu, W.; Wang, F.; Li, W. Study on the Implementation and Development of the Green Building in China. Appl. Mech. Mater. 2013, 438-439, 1662-1665. [CrossRef]

40. Liu, Y.; Lin, B. Green Building Development in China. In Green City Planning and Practices in Asian Cities; Shen, Z., Huang, L., Peng, K., Pai, J., Eds.; Springer: New York, NY, USA, 2018; pp. 77-108.

41. Ali, H.H.; Al Nsairat, S.F. Developing a green building assessment tool for developing countries-Case of Jordan. Build. Environ. 2009, 44, 1053-1064. [CrossRef]

42. Tso, G.K.F.; Yau, K.K.W.; Yang, C.Y. Sustainable Development Index in Hong Kong: Approach, Method and Findings. Soc. Indic. Res. 2011, 101, 93-108. [CrossRef]

43. Sheng, B. The Development of Green Building Materials Trend in China. In Architecture, Building Materials and Engineering Management, Pts 1-4; Hou, H., Tian, L., Eds.; TTP: Freienbach, Switzerland, 2013; Volume 357.

44. He, J. Efficient Development Scheme of Green Building. In Green Power, Materials and Manufacturing Technology and Applications III, Pts 1 and 2; Du, W.J., Ma, M., Eds.; TTP: Freienbach, Switzerland, 2014; Volume 484. 
45. Qin, Z.; Li, J.; Xu, Z. Research on the Evolution Mechanism and Countermeasures of Green Building Market Based on Evolutionary Game Theory. In Proceedings of the International Conference on Electronics, Mechanics, Culture and Medicine; Chang, L., Guiran, C., Zhen, L., Eds.; Atlantis Press: Paris, France, 2016; Volume 45, pp. 332-336.

46. Xiong, C.; Chen, J. Singapore's Aarden City Construction and Green Building Development. Available online: https://iopscience. iop.org/article/10.1088/1755-1315/153/6/062072/pdf (accessed on 13 November 2021).

47. Wang, W.; Xu, F.; Lu, P.; Zhou, J.; Wu, W. Development Status of Green Building in China. In Proceedings of the International Conference on Environmental and Water Resources Engineering, Seoul, Korea, 10-12 December 2018; pp. 129-139.

48. Ohama, Y.; Icmr, I. Recent Development of Sustainable Construction Materials in Japan. In Proceedings of the fourth international conference on materials engineering for resources, Akita, Japan, 15-16 December 2001; pp. 88-93.

49. Ming, L. Discuss on China's Green Building Materials Development. In Components, Packaging and Manufacturing Technology; Wu, Y.W., Ed.; TTP: Freienbach, Switzerland, 2011; Volume 460.

50. Shiau, Y.-C.; Lu, I.T.; Tsai, C.-I.; Lee, C.-Y. Research on the Green Building Revolution-Solar Energy Research and Development in Taiwan. In Green Power, Materials and Manufacturing Technology and Applications II; Zhong, S., Liu, Z., Eds.; TTP: Freienbach, Switzerland, 2012; Volume 214, pp. 505-509.

51. Corinaldesi, V.; Moriconi, G.; Tittarelli, F. SCC: A Way to Sustainable Construction Development. In Proceedings of the International Symposium on Design, Performance and Use of Self-Consolidating Concrete, Changsha, China, 10-13 May 2005; Volume 42, pp. 599-605.

52. Zhang, S.; Liu, H.; Wang, Y. New Trends of Green Building's Skin Material: Take the Solar Decathlon Europe 2010 for Example. In Construction and Urban Planning, Pts 1-4; Huang, Y., Bao, T., Wang, H., Eds.; TTP: Freienbach, Switzerland, 2013 ; Volume 671.

53. Saleh, A.M.; Rahmat, M.T.; Yusoff, M.F.N.; Eddirizal, N.E. Utilization of Palm Oil Fuel Ash and Rice Husks in Unfired Bricks for Sustainable Construction Materials Development. In Building Surveying, Facilities Management and Engineering Conference; Mydin, M.A.O., Salim, N.A.A., Eds.; EDP Sciences: Les Ulis, France, 2014.

54. Benghida, D. Earth Architecture: An Eco-Compatible Solution for Future Green Buildings. In Proceedings of the International Conference on Civil, Architectural, Structural and Constructional Engineering, South Korea, 21-23 August 2016; CRC Press; pp. 77-80.

55. Arslan, M.H.; Arslan, H.D. New Trends on Green Buildings: Investigation of the Feasibility of Using Plastic Members in RC Buildings with SWs. Available online: https:/ / www.proquest.com/docview/2560139340 (accessed on 13 November 2021).

56. Hartmann, R.; Jaeger, W. Sustainable building for the future: Contemporary clay masonry-Resource-saving building. Mauerwerk 2017, 21, 102-113. [CrossRef]

57. Taufani, B. Urban farming construction model on the vertical building envelope to support the green buildings development in Sleman, Indonesia. Procedia Eng. 2017, 171, 258-264.

58. Lu, Y.; Wu, Z.; Chang, R.; Li, Y. Building Information Modeling (BIM) for green buildings: A critical review and future directions. Autom. Constr. 2017, 83, 134-148. [CrossRef]

59. Huang, Y.; Wu, W.; Yang, S. Sustainable development of green building based on intuitionistic fuzzy analytic hierarchy process. Appl. Ecol. Environ. Res. 2019, 17, 1093-1108. [CrossRef]

60. Xu, S.; Yan, C.; Jin, C. Design Optimization of Hybrid Renewable Energy Systems for Sustainable Building Development based on Energy-Hub. Energy Procedia 2019, 158, 1015-1020. [CrossRef]

61. Jiang, X.; Lv, Y. An Empirical Analysis of the Development Factors of Green Buildings in the United States. In Proceedings of the Conference Proceedings of the 6th International Symposium on Project Management, Chongqing, China, 21 July 2018 ; pp. 50-56.

62. Huang, N.; Bai, L.; Wang, H.; Du, Q.; Shao, L.; Li, J. Social Network Analysis of Factors Influencing Green Building Development in China. Int. J. Environ. Res. Public Health 2018, 15, 2684. [CrossRef]

63. Teng, J.; Mu, X.; Wang, W.; Xu, C.; Li, W. Strategies for sustainable development of green buildings. Sustain. Cities Soc. 2019, 44, 215-226. [CrossRef]

64. Sharma, M. Development of a 'Green building sustainability model' for Green buildings in India. J. Clean. Prod. 2018, 190, 538-551. [CrossRef]

65. Wang, X.; Ren, H.; Cai, W.; Liu, Y.; Luo, L. Identification of driving factors for green building development in China. Open House Int. 2016, 41, 92-96. [CrossRef]

66. Ghazali, F.E.M.; Zakaria, R.; Aminudin, E.; Siang, L.Y.; Alqaifi, G.; Abas, D.N.; Abidin, N.I.; Shamsuddin, S.M. The Priority Importance of Economic Motivation Factors against Risks for Green Building Development in Malaysia. In 6th International Conference of Euro Asia Civil Engineering Forum; EDP Sciences: Les Ulis, France, 2017.

67. Hong-Trang, N.; Skitmore, M.; Gray, M.; Zhang, X.; Olanipekun, A.O. Will green building development take off? An exploratory study of barriers to green building in Vietnam. Resour. Conserv. Recycl. 2017, 127, 8-20.

68. Gomez, C.P.; Yung, G.T.T. Housing Industry Readiness Factors and Indicators to Implement Green Building Development. Int. J. Sustain. Constr. Eng. Technol. 2018, 9, 44-57. [CrossRef]

69. Dalibi, S.G.; Feng, J.C.; Liu, S.; Sadiq, A.; Bello, B.S.; Danja, I.I. Hindrances to Green Building Developments in Nigeria's Built Environment: "The Project Professionals' Perspectives". In Proceedings of the 2017 International Conference on Environmental and Energy Engineering, Suzhou, China, 22-24 March 2017.

70. Liu, Y.; Min, D.; Hu, K.; Destech Publicat, I. Green Building Policy in China: Evolution, Effects and Optimization. In Proceedings of the Asia Pacific Management and Engineering Conference, Shanghai, China, 29 November 2014; pp. 938-944. 
71. Kuo, C.-F. J.; Lin, C.-H.; Hsu, M.-W. Analysis of intelligent green building policy and developing status in Taiwan. Energy Policy 2016, 95, 291-303. [CrossRef]

72. Rabelo Albala, P.L.; Lorenzetti Lima, N.M.; da Cruz Noia, P.R.; Proenca, M.A.; Soares Goncalves, J.C.; Kronka Mulfarth, R.C. The Environmental Management Plan at University of Sao Paulo: A Methodology for Sustainable Buildings Policy and Its Further Developments. In Towards Green Campus Operations: Energy, Climate and Sustainable Development Initiatives at Universities; Filho, W.L., Frankenberger, F., Iglecias, P., Mulfarth, R.C.K., Eds.; Springer Publishing: New York, NY, 2018; pp. 441-456.

73. Czajkowska, A. The role of sustainable construction in sustainable development. In 3rd Scientific Conference Environmental Challenges in Civil Engineering; EDP Sciences: Les Ulis, France, 2018.

74. Quesada Molina, F. Development of new building sustainability assessment methods from the revision of the state of art. ACE-Archit. City Environ. 2018, 13, 51.

75. Liu, C.-P.; Chou, D.-C. Development of a Simplified Green Building Model in Taiwan: The Case of the AGS1 Experimental House. In Green City Planning and Practices in Asian Cities; Shen, Z., Huang, L., Peng, K., Pai, J., Eds.; Springer Publishing: New York, NY, 2018; pp. 275-299.

76. Isopescu, D.N. The impact of green building principles in the sustainable development of the built environment. Available online: https:/ /inis.iaea.org/search/search.aspx?orig_q=RN:52099356 (accessed on 13 November 2021).

77. Gibbs, D.; O'Neill, K. Rethinking sociotechnical transitions and green entrepreneurship: The potential for transformative change in the green building sector. Environ. Plan. A 2014, 46, 1088-1107. [CrossRef]

78. Kovalev, S.; Smorodina, E.; Rogacheva, Y.; Vasilyeva, O. Industry. In International Science Conference Spbwosce-2016-Smart City; EDP Sciences: Les Ulis, France, 2017.

79. Allen, J.H.; Potiowsky, T. Portland's Green Building Cluster Economic Trends and Impacts. Econ. Dev. Q. 2008, 22, 303-315. [CrossRef]

80. $\mathrm{Wu}, \mathrm{C}$. Analysis on Development and Economic Effect of Green Building. In Proceedings of the 2016 International Conference on Arts, Design and Contemporary Education, Moscow, Russia, 22-25 May 2016; McAnally, E., Hylind, M., Volodina, T., Zhang, Y., Solovjeva, I., Eds.; Volume 64, pp. 614-617.

81. Xing, Z.; Cao, X. Promoting Strategy of Chinese Green Building Industry: An Evolutionary Analysis Based on the Social Network Theory. IEEE Access 2019, 7, 67213-67221. [CrossRef]

82. Ban, J. Research on the Development Direction and Trend of Interior Design Education under the Green Building Background. In Proceedings of the 2016 2nd International Conference on Social Science and Technology Education, Guangzhou, China, 14-15 May 2016; Kim, Y., Ed.; Volume 55, pp. 928-933.

83. Gou, Z.; Xie, X. Evolving green building: Triple bottom line or regenerative design? J. Clean. Prod. 2017, 153, 600-607. [CrossRef]

84. Goel, A.; Ganesh, L.S.; Kaur, A. Deductive content analysis of research on sustainable construction in India: Current progress and future directions. J. Clean. Prod. 2019, 226, 142-158. [CrossRef]

85. Huo, X.; Yu, A.T.W. Analytical review of green building development studies. J. Green Build. 2017, 12, 130-148. [CrossRef]

86. $\mathrm{Xu}, \mathrm{Q}$. Essence Research on the Sustainable Development of Greening Building: From Green Building to Green Life. In Proceedings of the 2011 International Conference on Construction and Real Estate Management, Guangzhou, China, 19-20 November 2011; pp. 324-328.

87. Bojic, M. Net Sustainable Buildings: Approaching Future. In Proceedings of the Sixth Global Conference on Power Control and Optimization, Las Vegas, Nevada, USA, 20 November 2012; Barsoum, N., Faiman, D., Vasant, P., Eds.; Volume 1499, pp. 63-70.

88. Ade, R.; Rehm, M. The unwritten history of green building rating tools: A personal view from some of the 'founding fathers'. Build. Res. Inf. 2019, 48, 1-17. [CrossRef]

89. Wang, S.H.-M.; Williams, P.; Shi, J.; Yang, H. From Green to Sustainability-Trends in the Assessment Methods of Green Buildings. Front. Eng. Manag. 2015, 2, 114-121. [CrossRef]

90. Goh, B.H.; Sun, Y. The development of life-cycle costing for buildings. Build. Res. Inf. 2016, 44, 319-333. [CrossRef]

91. Mourtada, A.; Mourtada, R.; Eid, S. IEEE, Development of Practical Guidelines and Tools for GRASS green buildings rating system. In Proceedings of the 2018 4th International Conference on Renewable Energies for Developing Countries, Beirut, Lebanon, 1-2 November 2018; pp. 1-7.

92. Lohmeng, A.; Sudasna, K.; Tondee, T. State of The Art of Green Building Standards and Certification System Development in Thailand. Energy Procedia 2017, 138, 417-422. [CrossRef]

93. Graves, R.; Smith, P. Minnesota Sustainable Building Guidelines: History, Effectiveness and Path for the Future. J. Green Build. 2018, 13, 163-180. [CrossRef]

94. Thomson, C.S.; El-Haram, M.A. Is the evolution of building sustainability assessment methods promoting the desired sharing of knowledge amongst project stakeholders? Constr. Manag. Econ. 2019, 37, 433-460. [CrossRef]

95. Ferwati, M.S.; Al Saeed, M.; Shafaghat, A.; Keyvanfar, A. Qatar Sustainability Assessment System (QSAS)-Neighborhood Development (ND) Assessment Model: Coupling green urban planning and green building design. J. Build. Eng. 2019, 22, 171-180. [CrossRef]

96. Houghton, A. Health Impact Assessments-A Tool for Designing Climate Change Resilience into Green Building and Planning Projects. J. Green Build. 2011, 6, 66-87. [CrossRef]

97. Todd, J.A.; Pyke, C.; Tufts, R. Implications of trends in LEED usage: Rating system design and market transformation. Build. Res. Inf. 2013, 41, 384-400. [CrossRef] 
98. Meshcheryakova, T. Problems of the development of international standards of "green building" in Russia. Available online: https://www.researchgate.net/publication/327113591_Green_Building_in_Moscow_Problems_and_Contradictions/link/ 5b7ab1df299bf1d5a7174439/download (accessed on 13 November 2021).

99. Sobek, W. Essay: The Future of Sustainable Architecture: Ressources, Recyclability and Ultra-Lightweight. Archit. Urban. 2014, $524,6-13$.

100. Ruebenich, I.T.C.; de Oliveira, T.D. Technology of Earthships and the Future of Sustainable Architecture-Search on the Feasibility and Impact of Self-Sufficient Living in Urban Areas. Rev. Gedecon Rev. Gest. Desenvolv. Contexto 2015, 3, 25-36.

101. Hager, I.; Golonka, A.; Putanowicz, R. 3D printing of buildings and building components as the future of sustainable construction? Procedia Eng. 2016, 151, 292-299. [CrossRef]

102. Wen, B.; Musa, N.; Onn, C.C.; Ramesh, S.; Liang, L.; Wang, W. Evolution of sustainability in global green building rating tools. J. Clean. Prod. 2020, 259, 120912. [CrossRef]

103. Fanney, A.H.; Whitter, K.M.; Traugott, A.E.; Simon, L.N. US Green Building Conference-1994; National Institute of Standards and Technology: Gaithersburg, MD, USA, 1994.

104. Crosbie, M.J. Green Architecture: A Guide to Sustainable Design; Rockport Publishers: Gloucester, MA, USA, 1994.

105. Fanney, A.H.; Whitter, K.M.; Cohn, T.B. Second International Green Building Conference and Exposition-1995; US Department of Commerce, Technology Administration, National Institute of Standards and Technology (U.S.): Washington, DC, USA, 1995.

106. Kibert, C.J. Principles of sustainable construction. In Proceedings of the First International Conference on Sustainable Construction, Tampa, Florida, USA, 6-9 November 1994; pp. 1-9.

107. Martek, I.; Hosseini, M.R.; Shrestha, A.; Zavadskas, E.K.; Seaton, S. The Sustainability Narrative in Contemporary Architecture: Falling Short of Building a Sustainable Future. Sustainability 2018, 10, 981. [CrossRef]

108. Mazmanian, D.A.; Kraft, M.E. Toward Sustainable Communities: Transition and Transformations in Environmental Policy; MIT Press: Cambridge, MA, USA, 2009.

109. Zuo, J.; Zhao, Z.-Y. Green building research-current status and future agenda: A review. Renew. Sustain. Energy Rev. 2014, 30, 271-281. [CrossRef]

110. Berardi, U. Clarifying the new interpretations of the concept of sustainable building. Sustain. Cities Soc. 2013, 8, 72-78. [CrossRef]

111. Zuo, J.; Jin, X.-H.; Flynn, L. Social Sustainability in Construction-An Explorative Study. Int. J. Constr. Manag. 2012, 12, 51-63. [CrossRef]

112. Doan, D.T.; Ghaffarianhoseini, A.; Naismith, N.; Zhang, T.R.; Tookey, J. A critical comparison of green building rating systems. Build. Environ. 2017, 123, 243-260. [CrossRef]

113. Pan, W.; Ning, Y. Dialectics of sustainable building: Evidence from empirical studies 1987-2013. Build. Environ. 2014, 82, 666-674. [CrossRef]

114. Khan, J.S.; Zakaria, R.; Shamsudin, S.M.; Abidin, N.I.A.; Sahamir, S.R.; Abbas, D.N.; Aminudin, E. Evolution to Emergence of Green Buildings: A Review. Adm. Sci. 2019, 9, 6. [CrossRef]

115. Lowe, R. Addressing the Challenges of Climate Change for the Built Environment; Taylor \& Francis: Abingdon, UK, 2007.

116. Awadh, O. Sustainability and green building rating systems: LEED, BREEAM, GSAS and Estidama critical analysis. J. Build. Eng. 2017, 11, 25-29. [CrossRef]

117. Hoffman, A.J.; Henn, R.J. Overcoming the social and psychological barriers to green building. Organ. Environ. 2008, 21, 390-419. [CrossRef]

118. Wu, P.; Low, S.P. Project Management and Green Buildings: Lessons from the Rating Systems. J. Prof. Issues Eng. Educ. Pract. 2010, 136, 64-70. [CrossRef]

119. Aras, G.; Crowther, D. Making sustainable development sustainable. Manag. Decis. 2009, 47, 975-988. [CrossRef]

120. Dwaikat, L.N.; Ali, K.N. Green buildings cost premium: A review of empirical evidence. Energy Build. 2016, 110, 396-403. [CrossRef]

121. Wei, W.J.; Ramalho, O.; Mandin, C. Indoor air quality requirements in green building certifications. Build. Environ. 2015, 92, 10-19. [CrossRef]

122. Abdellatif, M.; Al-Shamma'a, A. Review of sustainability in buildings. Sustain. Cities Soc. 2015, 14, 171-177. [CrossRef]

123. Thatcher, A.; Milner, K. Is a green building really better for building occupants? A longitudinal evaluation. Build. Environ. 2016, 108, 194-206. [CrossRef]

124. Marjaba, G.E.; Chidiac, S.E. Sustainability and resiliency metrics for buildings-Critical review. Build. Environ. 2016, 101, 116-125. [CrossRef]

125. Yuan, X.; Zuo, J. A critical assessment of the Higher Education for Sustainable Development from students' perspectives-A Chinese study. J. Clean. Prod. 2013, 48, 108-115. [CrossRef]

126. Berardi, U. Chapter 15-Sustainability assessments of buildings, communities, and cities. In Assessing and Measuring Environmental Impact and Sustainability; Klemeš, J.J., Ed.; Butterworth-Heinemann: Oxford, UK, 2015; pp. 497-545.

127. Ghoddousi, P.; Nasirzadeh, F.; Hashemi, H. Evaluating Highway Construction Projects' Sustainability Using a Multicriteria Group Decision-Making Model Based on Bootstrap Simulation. J. Constr. Eng. Manag. 2018, 144, 04018092. [CrossRef]

128. Xie, H.J.; Clements-Croome, D.; Wang, Q.K. Move beyond green building: A focus on healthy, comfortable, sustainable and aesthetical architecture. Intell. Build. Int. 2017, 9, 88-96. [CrossRef]

129. Edwards, B. Rough Guide to Sustainability; RIBA Publishing: London, UK, 2010. 
130. Sjostrom, C.; Bakens, W. CIB Agenda 21 for sustainable construction: Why, how and what. Build. Res. Inf. 2010, $27,347-353$. [CrossRef]

131. Chehrzad, M.; Pooshideh, S.M.; Hosseini, A.; Sardroud, J.M. A review on green building assessment tools: Rating, calculation and decision-making. In Proceedings of the Sustainable City Xi, GalianoGarrigos, Alicante, Spain, 12-14 July 2016; Volume 204, pp. 397-404.

132. Su, Y.M.; Lin, C.H. The Relationship between Taiwan Green Buildings, Humanity and Aesthetics. Appl. Mech. Materials. 2014, 496-500, 2538-2543. [CrossRef]

133. Wang, N.; Phelan, P.E.; Harris, C.; Langevin, J.; Nelson, B.; Sawyer, K. Past visions, current trends, and future context: A review of building energy, carbon, and sustainability. Renew. Sustain. Energy Rev. 2018, 82, 976-993. [CrossRef]

134. Hwang, B.-G.; Ng, W.J. Project management knowledge and skills for green construction: Overcoming challenges. Int. J. Proj. Manag. 2013, 31, 272-284. [CrossRef]

135. Sang, P.; Liu, J.; Zhang, L.; Zheng, L.; Yao, H.; Wang, Y. Effects of project manager competency on green construction performance: The Chinese context. Sustainability 2018, 10, 3406. [CrossRef]

136. Zhang, Y.; Kang, J.; Jin, H. A Review of Green Building Development in China from the Perspective of Energy Saving. Energies 2018, 11, 334. [CrossRef]

137. Mohamad Bohari, A.A.; Skitmore, M.; Xia, B.; Teo, M.; Zhang, X.; Adham, K.N. The path towards greening the Malaysian construction industry. Renew. Sustain. Energy Rev. 2015, 52, 1742-1748. [CrossRef]

138. Gu, Z.; Wennersten, R.; Assefa, G. Analysis of the most widely used Building Environmental Assessment methods. Environ. Sci. 2006, 3, 175-192. [CrossRef]

139. Ding, G.K. Sustainable construction-The role of environmental assessment tools. J. Environ. Manag. 2008, 86, 451-464. [CrossRef] [PubMed]

140. Mao, X.; Lu, H.; Li, Q. A Comparison study of mainstream sustainable/green building rating tools in the world. In Proceedings of the 2009 International Conference on Management and Service Science, Beijing, China, 20-22 September 2009; pp. 1-5.

141. Aktas, B.; Ozorhon, B. Green building certification process of existing buildings in developing countries: Cases from Turkey. J. Manag. Eng. 2015, 31, 05015002. [CrossRef]

142. Sev, A. How can the construction industry contribute to sustainable development? A conceptual framework. Sustain. Dev. 2009, 17, 161-173. [CrossRef]

143. Illankoon, I.M.C.S.; Tam, V.W.Y.; Le, K.N. Environmental, Economic, and Social Parameters in International Green Building Rating Tools. J. Prof. Issues Eng. Educ. Pract. 2017, 143, 05016010. [CrossRef]

144. Mattoni, B.; Guattari, C.; Evangelisti, L.; Bisegna, F.; Gori, P.; Asdrubali, F. Critical review and methodological approach to evaluate the differences among international green building rating tools. Renew. Sustain. Energy Rev. 2018, 82, 950-960. [CrossRef]

145. Newsham, G.R.; Mancini, S.; Birt, B.J. Do LEED-certified buildings save energy? Yes, but ... . Energy Build. 2009,8 , 897-905. [CrossRef]

146. Al-Ghamdi, G.; Bilec, M.M. Whole-Building LCA and Green Building Rating Systems: Exploratory Review of the Available Tools. Available online: file:/ / C:/Users/MDPI/AppData/Local/Temp/AlGhamdiWholeBuildingLCA.pdf (accessed on 13 November 2021).

147. Ortiz, O.; Castells, F.; Sonnemann, G. Sustainability in the construction industry: A review of recent developments based on LCA. Constr. Build. Mater. 2009, 23, 28-39. [CrossRef]

148. Ismaeel, W.S.E. Drawing the operating mechanisms of green building rating systems. J. Clean. Prod. 2019, 213, 599-609. [CrossRef]

149. Dekkiche, H.; Taileb, A. The Importance of Integrating LCA into the LEED Rating System. Procedia Eng. 2016, 145, 844-851. [CrossRef]

150. Ismaeel, W.S.E. Midpoint and endpoint impact categories in Green building rating systems. J. Clean. Prod. 2018, 182, 783-793. [CrossRef]

151. Suzer, O. A comparative review of environmental concern prioritization: LEED vs. other major certification systems. J. Environ. Manag. 2015, 154, 266-283. [CrossRef]

152. Chew, M.Y.L.; Das, S. Building grading systems: A review of the state-of-the-art. Archit. Sci. Rev. 2008, 51, 3-13. [CrossRef]

153. Reed, M.S.; Fraser, E.D.G.; Dougill, A.J. An adaptive learning process for developing and applying sustainability indicators with local communities. Ecol. Econ. 2006, 59, 406-418. [CrossRef]

154. Herda, G.; Autio, V. Building Sustainability Assessment and Benchmarking; United Nations Settlements Programme (UN-Habitat): Nairobi, Kenya, 2017.

155. Rumsey, P.; McLellan, J.F. The green edge-The green imperative. Environ. Des. Constr. 2005, 7, 55-56.

156. Schendler, A. LEED Is Broken; Let's Fix, It. Available online: https://drive.google.com/file/d/0B1pYffuHFkvlY2 YwZDdiYjAtNzIwYi00YjNjLTlmMzgtZDYwZTQ2OThlOTAw/view?sort=name\&layout=list\&num=50\&resourcekey=0h2FRrswR3v-FO8-UQqX8yw (accessed on 13 November 2021).

157. Li, Y.; Chen, X.; Wang, X.; Xu, Y.; Chen, P.-H. A review of studies on green building assessment methods by comparative analysis. Energy Build. 2017, 146, 152-159. [CrossRef]

158. Alyami, S.H.; Rezgui, Y. Sustainable building assessment tool development approach. Sustain. Cities Soc. 2012, 5, 52-62. [CrossRef]

159. Zimmermann, R.K.; Skjelmose, O.; Jensen, K.G.; Jensen, K.K.; Birgisdottir, H. Categorizing Building Certification Systems According to the Definition of Sustainable Building. IOP Conf. Ser. Mater. Sci. Eng. 2019, 471, 092060. [CrossRef] 
160. Bernardi, E.; Carlucci, S.; Cornaro, C.; Bohne, R. An Analysis of the Most Adopted Rating Systems for Assessing the Environmental Impact of Buildings. Sustainability 2017, 9, 1226. [CrossRef]

161. Al-Ghamdi, S.G.; Bilec, M.M. Life-Cycle Thinking and the LEED Rating System: Global Perspective on Building Energy Use and Environmental Impacts. Environ. Sci. Technol. 2015, 49, 4048-4056. [CrossRef]

162. He, Y.; Kvan, T.; Liu, M.; Li, B. How green building rating systems affect designing green. Build. Environ. 2018, 133, 19-31. [CrossRef]

163. Ding, Z.; Fan, Z.; Tam, V.W.Y.; Bian, Y.; Li, S.; Illankoon, I.M.C.S.; Moon, S. Green building evaluation system implementation. Build. Environ. 2018, 133, 32-40. [CrossRef]

164. Rastogi, A.; Choi, J.-K.; Hong, T.; Lee, M. Impact of different LEED versions for green building certification and energy efficiency rating system: A Multifamily Midrise case study. Appl. Energy 2017, 205, 732-740. [CrossRef]

165. Wu, P.; Song, Y.; Shou, W.; Chi, H.; Chong, H.-Y.; Sutrisna, M. A comprehensive analysis of the credits obtained by LEED 2009 certified green buildings. Renew. Sustain. Energy Rev. 2017, 68, 370-379. [CrossRef]

166. Gou, Z.; Lau, S.S.-Y. Contextualizing green building. Rating systems: Case study of Hong Kong. Habitat Int. 2014, 44, 282-289. [CrossRef] [PubMed]

167. Jensen, K.G.; Poulsgaard, K.S.; Lind, L.; Christensen, C.Ø.; Skjelmose, O.; Carruth, S.J.; Jensen, K.K.; Canera, I.O.; Manbodh, J.; Birgisdottir, H. Guide to Sustainable Building Certifications; Danish Building Research Institute: Copenhagen, Denmark, 2018.

168. Wang, J.-J.; Zhang, Y.-R.; Wang, Y.-F. Comparison of both Old and New Versions of the Evaluation Standard for Green Building in China with LEED in American. In Low-Carbon City and New-Type Urbanization; Feng, S., Huang, W., Wang, J., Wang, M., Zha, J., Eds.; Springer: Berlin, Heidelberg, 2015; pp. 89-99.

169. Lee, W.L. A comprehensive review of metrics of building environmental assessment schemes. Energy Build. 2013, 62, 403-413. [CrossRef]

170. Park, J.; Yoon, J.; Kim, K.-H. Critical Review of the Material Criteria of Building Sustainability Assessment Tools. Sustainability 2017, 9, 186. [CrossRef]

171. Díaz López, C.; Carpio, M.; Martín-Morales, M.; Zamorano, M. A comparative analysis of sustainable building assessment methods. Sustain. Cities Soc. 2019, 49, 101611. [CrossRef]

172. Deng, Y.; Wu, J. Economic returns to residential green building investment: The developers' perspective. Reg. Sci. Urban Econ. 2014, 47, 35-44. [CrossRef]

173. Gou, Z.; Prasad, D.; Lau, S.S.-Y. Impacts of green certifications, ventilation and office types on occupant satisfaction with indoor environmental quality. Archit. Sci. Rev. 2014, 57, 196-206. [CrossRef]

174. Khoshbakht, M.; Gou, Z.; Xie, X.; He, B.; Darko, A. Green building occupant satisfaction: Evidence from the australian higher education sector. Sustainability 2018, 10, 2890. [CrossRef]

175. Piasecki, M.; Kozicki, M.; Firlag, S.; Goljan, A.; Kostyrko, K. The approach of including tvocs concentration in the indoor environmental quality model (ieq)—Case studies of breeam certified office buildings. Sustainability 2018, 10, 3902. [CrossRef]

176. Xue, F.; Lau, S.S.; Gou, Z.; Song, Y.; Jiang, B. Incorporating biophilia into green building rating tools for promoting health and wellbeing. Environ. Impact Assess. Rev. 2019, 76, 98-112. [CrossRef]

177. Gou, Z.; Prasad, D.; Lau, S.S.-Y. Are green buildings more satisfactory and comfortable? Habitat Int. 2013, 39, 156-161. [CrossRef]

178. Xue, F.; Gou, Z.; Lau, S. Human factors in green office building design: The impact of workplace green features on health perceptions in high-rise high-density Asian cities. Sustainability 2016, 8, 1095. [CrossRef]

179. Yeang, K.J. Green Design. In Future Office; Taylor \& Francis: Abingdon, UK, 2013; p. 105.

180. Byrd, H.; Rasheed, E.O. The Productivity Paradox in Green Buildings. Sustainability 2016, 8, 347. [CrossRef]

181. Anand, C.K.; Amor, B. Recent developments, future challenges and new research directions in LCA of buildings: A critical review. Renew. Sustain. Energy Rev. 2017, 67, 408-416. [CrossRef]

182. Lotteau, M.; Loubet, P.; Pousse, M.; Dufrasnes, E.; Sonnemann, G. Critical review of life cycle assessment (LCA) for the built environment at the neighborhood scale. Build. Environ. 2015, 93, 165-178. [CrossRef]

183. Alberti, J.; Balaguera, A.; Brodhag, C.; Fullana-i-Palmer, P. Towards life cycle sustainability assessent of cities. A review of background knowledge. Sci. Total Environ. 2017, 609, 1049-1063. [CrossRef] [PubMed]

184. Wu, P.; Song, Y.Z.; Hu, X.; Wang, X.Y. A Preliminary Investigation of the Transition from Green Building to Green Community: Insights from LEED ND. Sustainability 2018, 10, 1802. [CrossRef]

185. Cole, R.J. Building environmental assessment methods: Clarifying intentions. Build. Res. Inf. 1999, 27, 230-246. [CrossRef]

186. Scheuer, C.W.; Scheuer, C.W. Evaluation of LEED Using Life Cycle Assessment Methods; US Department of Commerce, National Institute of Standards and Technology: Gaithersburg, MD, USA, 2002.

187. Bowyer, D.; Howe, D.J.; Fernholz, K.; Lindburg, A. Designation of Environmentally Preferable Building Materials Fundamental Change Needed within LEED; Dovetail Partners Inc.: White Bear Lake, MN, USA, 2006.

188. Kibert, C.J. Sustainable Construction: Green Building Design and Delivery; John Wiley \& Sons: Hoboken, NJ, USA, 2016.

189. Bragança, L.; Mateus, R.; Koukkari, H. Assessment of Building Sustainability. Sustainability. 2010, 2, 2010-2023. [CrossRef]

190. AbdelAzim, A.I.; Ibrahim, A.M.; Aboul-Zahab, E.M. Development of an energy efficiency rating system for existing buildings using Analytic Hierarchy Process-The case of Egypt. Renew. Sustain. Energy Rev. 2017, 71, 414-425. [CrossRef]

191. Cole, R.J. Building environmental assessment methods: Redefining intentions and roles. Build. Res. Inf. 2005, 33, 455-467. [CrossRef] 
192. Kaatz, E.; Root, D.S.; Bowen, P.A.; Hill, R.C. Advancing key outcomes of sustainability building assessment. Build. Res. Inf. 2006, 34, 308-320. [CrossRef]

193. Kubba, S. Handbook of Green Building Design, and Construction: LEED, BREEAM, and Green Globes; Butterworth-Heinemann: Oxford, UK, 2012; pp. 1-820.

194. Alyami, S.H.; Rezgui, Y.; Kwan, A. The development of sustainable assessment method for Saudi Arabia built environment: Weighting system. Sustain. Sci. 2015, 10, 167-178. [CrossRef]

195. Hakkinen, T.; Belloni, K. Barriers and drivers for sustainable building. Build. Res. Inf. 2011, 39, 239-255. [CrossRef]

196. Kang, H.; Lee, Y.; Kim, S. Sustainable building assessment tool for project decision makers and its development process. Environ. Impact Assess. Rev. 2016, 58, 34-47. [CrossRef] 